INSTITUTE OF FORESTRY • BELGRADE

INSTITUT ZA ŠUMARSTVO • BEOGRAD

SUSTAINABLE FORESTRY

COLLECTION 69-70, 2014
ODRŽIVO ŠUMARSTVO

ZBORNIK RADOVA 69-70, 2014

UDK $630 * 232.322 .4=111$

Original scientific paper

\title{
THE EFFECT OF APPLICATION OF MICROBIOLOGICAL PREPARATION ON HEIGHT GROWTH DYNAMICS OF ONE-YEAR OLD SEEDLING OF BLACK WALNUTE (Juglans nigra L.)
}

\author{
Tatjana ĆIRKOVIĆ-MITROVIĆ
}

\begin{abstract}
Trend of organic production of plants that are used for human nutrition binds that when using nutrition preparations which represent significant factor in production of high quality planting material for different purposes microbiological preparations have to be included as well. The effect of the microbiological preparation Bactofil $^{\mathbb{B}}$ B 10 on height growth tempo of black walnut seedlings during vegetation period is a subject of research of this paper. Comparative analysis of height increment of seedlings grown in soil treated with this preparation and height increment of control, nontreated seedlings shows the justification of direct application of Bactofil in mass production of high quality planting material of black walnut.
\end{abstract}

Key words: Black walnut, nursery production, microbiological preparation Bactofil $^{\mathbb{B}}$ B 10, height growth.

\section{ЕФЕКАТ ПРИМЕНЕ МИКРОБИОЛОШКОГ ПРЕПАРАТА НА ДИНАМИКУ ВИСИНСКИ ПОРАСТА ЈЕДНОГОДИШЫИХ САДНИЦА ЦРНОГ ОРАХА (Juglans nigra L.)}

Извод: Тренд органске производње биљака које се користе за људску исхрану обавезује да код коришћења препарата исхране, који представљају значајан фактор у производюи квалитетног садног материјала за различите намене, микробиолошки препарати треба да буду укључени. Предмет истраживања овог рада је утииај примене микробиолошког препарата Bactofil ${ }^{\circledR}$ B 10 на динамику висинског раста саднииа ирног ораха током вегетаиионог периода. Упоредна

\footnotetext{
${ }^{1}$ Dr Tatjana Ćirković-Mitrović, Institute of Forestry, Kneza Viseslava 3, Belgrade, Serbia, e-mailtanjacirk@yahoo.com

Translation: Dragana Popović
} 
анализа висине прираста садница раслих у супстрату и третираних овим препаратом и висински прираст контролних, нетретираних садница показује оправданост директне примене Bactofil-a у масовној производюи висококвалитетног садног материјала ирног ораха.

Кључне речи: црни орах, расадничка производња, микробиолошки препарат Bactofil $^{\circledR}$ B 10, висински раст

\section{INTRODUCTION}

Forest fruit trees have an enormous importance and their preservation, improvement and sustainable use in natural habitats are in accordance with the general interest for preservation of the biodiversity in Serbia. Range of many fruit trees in Serbia has declined alarmingly in the past 50 years and production of seedlings and their introduction into existing forests as well as afforestation of bare land contributes to the improvement of natural biological wealth of Serbia.

Initial planting material is of major importance for the success of afforestation. Using of poor quality planting material increases the costs of establishment and maintenance of cultures, while the success of afforestation is diminished (Oliet, J. A. et al., 2009). Previous experience in afforestation proved that a good selection of species and planting material characteristics (development of root system, resistance to temperature extremes, etc.) are very important for afforestation and must be taken into consideration.

Certain scientific researches have proved that application of nutrition preparations in contemporary seedling production represents not only an additional source of nutrients, but also a powerful mean and important factor in production of high-yielding planting material for various purposes. Trend of organic production of plants that are used for human nutrition binds that when using nutrition preparations which represent significant factor in production of high quality planting material for different purposes microbiological preparations have to be included as well.

\section{MATERIAL AND METHOD}

For the purpose of research and analysis of heights and height increment during vegetation period of black walnut seedlings and monitoring the effects of the microbiological preparation Bactofil $^{\mathbb{B}}$ B 10 a sample plot was established in the seedling nursery of the Institute of Forestry in Belgrade. The nursery is located at $20^{\circ} 27^{\prime} 44^{\prime \prime}$ east longitude and $44^{\circ} 49^{\prime} 14^{\prime \prime}$ north latitude.

By processing of data of Meteorological Service of Serbia for Weather station in Belgrade for the period from 1980 to 2009, we have obtained the average monthly air temperature and average monthly and annual precipitation for the site where the experiment was set up. Based on the obtained data we got and the average monthly amount of precipitation and average monthly temperature in the vegetative period. 
The black walnut seed collected in 2010 was used for establishment of sample plot. Seed was collected from tree, which grows in arboretum of Forest Faculty in Belgrade.

Due to dormancy of embryo, the black walnut seed was held in a wet stratification from November 2010 to the end of March 2011 (at the temperature 3$5{ }^{\circ} \mathrm{C}$ ). The sowing was performed in April 2011, in rows, 8-10 pieces per linear meter, at the depth of $8 \mathrm{~cm}$.

The seed was planted in Tref TPS fine brown substrate, produced by TREF Group, Jiffy product international AS from Norway. For its production is used peat moss from Estonia which does not contain weeds, dirt and pathogens, of fraction $<8 \mathrm{~mm}$ and $\mathrm{pH} 5.8( \pm 0,3)$, and represents a mixture of peat moss and perlite in a 9:1 ratio, while peat moss is a mixture containing $70 \%$ of white peat moss and $30 \%$ of black peat moss.

The analysis of height growth was performed on seedlings that were not treated with nutrition preparations, so-called ,control seedlings”, $\mathrm{K}$, and on seedlings that were treated with microbiological preparation Bactofil $^{\mathbb{R}}$ B 10, B.

Bactofil is a micro-biological fertilizer that contains ten most important sorts of soil bacteria, which enable optimum soil conditions for plant growth and development. Bacteria perform an irreplaceable role in sustainment of soil fertility by binding nitrogen from air and transforming it into a form that is easily accessible to plants. Furthermore, they increase phosphorus and potassium reserves in soil and help with decomposition of organic matter. Bacteria in Bactofil preparation are: Azotobacter vinelandii, Azospirilium brasilense, Azospirilium lipoferum, Bacillus, Pseudomonas, Bacillus subtilis, Bacillus polymyxa, Bacillus cirkulans, Streptomyces albus, Micrococcus roseus. By its addition to the substrate, Bactofil directly influences the intensity of humification and mineralisation process.

Data processing was performed by relevant procedures using statistical software packages (Statistica 7).

\section{RESULTS AND DISCUSSION}

\section{Climatic characteristics}

The average air temperature is $12.5^{\circ} \mathrm{C}$, while the average temperature in vegetation period is $19.2{ }^{\circ} \mathrm{C}$. The temperature reaches the lowest values in January (the average value for this month is $1.3{ }^{\circ} \mathrm{C}$ ), while the hottest month is July with $22.9^{\circ} \mathrm{C}$.

The total annual precipitation sum is $692 \mathrm{~mm}$, while in the vegetation period it amounts to $393 \mathrm{~mm}$, which is $57 \%$ of the total annual amount.

High amount of precipitation in the vegetation period is of particular importance for development, growth and increment of all plant species. The rainiest month is June, while the lowest amount of precipitation is recorded in February. A secondary precipitation maximum, with lower values, is reached in December, while a secondary minimum occurs in October (Ćirković-Mitrović, T. et al. 2012, 2012a). 


\section{Variation of height increment of one-year-old black walnut seedlings contingent upon treatment by Bactofil B10}

The statistical analysis of height of the black walnut seedling upon the treatment by preparations Bactofil indicates that after a more or less uniform increase in height at the beginning of the vegetation period comes to an increasing of differentiation of this morphometric marker in plants treated with Bactofil in comparison with the control seedlings. (table 1).

At the end of the vegetation period, the seedling with the absolute smallest height was measured in non-treated seedlings, and seedling with the absolute largest height was measured in seedlings treated with Bactofile. The smallest seedling has height of $25.0 \mathrm{~cm}$, and the highest seedling has height of $73.8 \mathrm{~cm}$. Also, the larger average height of $52.0 \mathrm{~cm}$ have seedlings treated with Bactofil. The average height of $21.61 \mathrm{~cm}$ have non-treated seedlings (table 1).

Table 1. Descriptive Statistics for control and treatment with Bactofil ( $K$ and $B$ )

\begin{tabular}{|c|r|r|r|r|r|c|}
\hline Treatment & Mean & Minimum & Maximum & Variance & $\begin{array}{c}\text { Stdand. } \\
\text { Dev. }\end{array}$ & $\begin{array}{c}\text { Standard } \\
\text { Error }\end{array}$ \\
\hline K & $44.8^{\mathrm{a}}$ & 25.0 & 69.9 & 96.26932 & 9.811693 & 1.034243 \\
\hline $\mathbf{B}$ & $52.0^{\mathrm{b}}$ & 27.1 & 73.8 & 82.61024 & 9.089017 & 0.958067 \\
\hline
\end{tabular}

After intense height increment at the beginning of the vegetative period (until June-July) in treatments, this morphometric parameter began to show a declining trend. the height increment decreases abruptly. Height increment of nontreated seedlings statistically differs significantly from height increment of seedlings from other treatment. At the end of the vegetation period, before the start of vegetative rest, the height increment of all seedlings is uniformed, with no significant differences. The curves of height development also indicate these trends (table 2, 3, Graph 1,2). In June starts the differentiation of heights of seedlings treated with Bactofil, and by the end of the vegetation period this parameter is significantly different compared to the heights of non-treated seedlings

Table 2. The difference in the height of black walnut seedlings during the growing season in 2011

\begin{tabular}{|c|c|c|c|c|c|}
\hline & \multicolumn{5}{|c|}{ height (cm) in month: } \\
\hline Treatment & VI & VII & VIII & IX & X \\
\hline K & $35.7^{\mathrm{a}}$ & $42.9^{\mathrm{a}}$ & $43.8^{\mathrm{a}}$ & $44.7^{\mathrm{a}}$ & $44.8^{\mathrm{a}}$ \\
\hline B & $37.4^{\mathrm{a}}$ & $47.7^{\mathrm{b}}$ & $50.5^{\mathrm{b}}$ & $51.7^{\mathrm{b}}$ & $52.0^{\mathrm{b}}$ \\
\hline & $\begin{array}{c}\mathrm{F}(1.178)=1.3146 \\
\mathrm{p}=0.25311\end{array}$ & $\begin{array}{c}\mathrm{F}(1.178)=10.593 \\
\mathrm{p}=0.00136\end{array}$ & $\begin{array}{c}\mathrm{F}(1.178)=22.090 \\
\mathrm{p}=0.00001\end{array}$ & $\begin{array}{c}\mathrm{F}(1.178)=24.491 \\
\mathrm{p}=0.00000\end{array}$ & $\begin{array}{c}\mathrm{F}(1.178)=25.824 \\
0.00000\end{array}$ \\
\hline
\end{tabular}

Mean values in the same column followed by different letters are statistically different for $r<0.05$ (Post hoc Tukey's HSD test) 


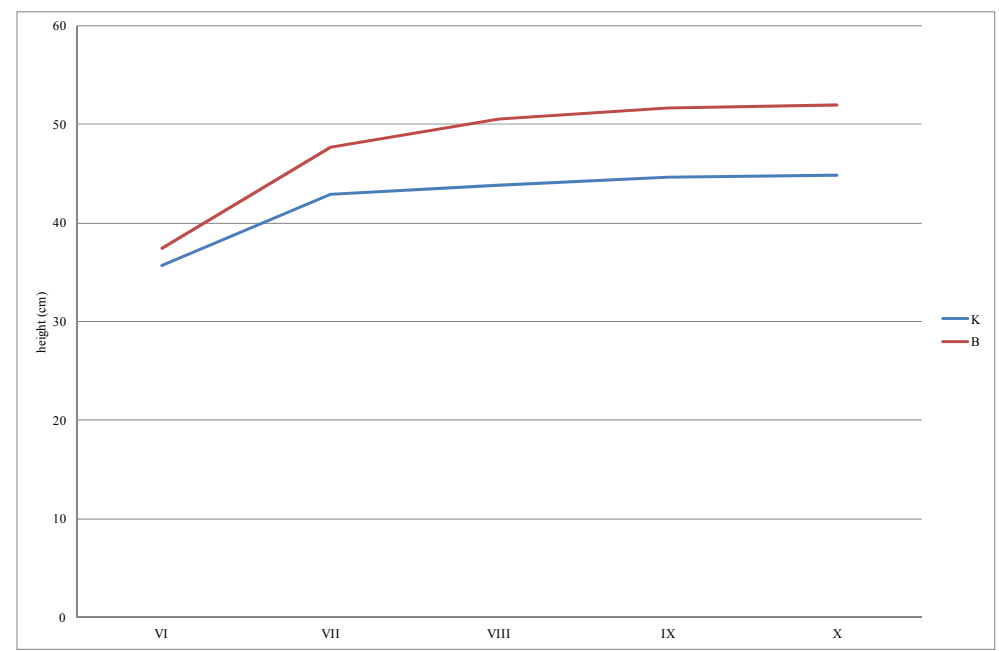

Graph 1. Development of height of black walnut (Juglans nigra L.) seedlings during the vegetation period

Table 3. The difference in the height increment of black walnut seedlings during the growing season in 2011

\begin{tabular}{|c|c|c|c|c|}
\hline & \multicolumn{4}{|c|}{ height increment in period: } \\
\hline Treatment & VI-VII & VII-VIII & VIII-IX & IX-X \\
\hline K & $7.23^{\mathrm{a}}$ & $0.90^{\mathrm{a}}$ & $0.83^{\mathrm{a}}$ & $0.16^{\mathrm{a}}$ \\
\hline $\mathbf{B}$ & $10.28^{\mathrm{b}}$ & $2.80^{\mathrm{b}}$ & $1.16^{\mathrm{b}}$ & $0.31^{\mathrm{b}}$ \\
\hline & $\mathrm{F}(1.178)=26.059$ & $\mathrm{~F}(1.178)=28.308$ & $\mathrm{~F}(1.178)=7.84$ & $\mathrm{~F}(1.178)=2.6553$ \\
$\mathrm{p}=0.00000$ & $\mathrm{p}=0.00000$ & $\mathrm{p}=0.00568$ & $\mathrm{p}=0.10497$ \\
\hline
\end{tabular}

Mean values in the same column followed by different letters are statistically different for $\mathrm{r}<0.05$ (Post hoc Tukey's HSD test)

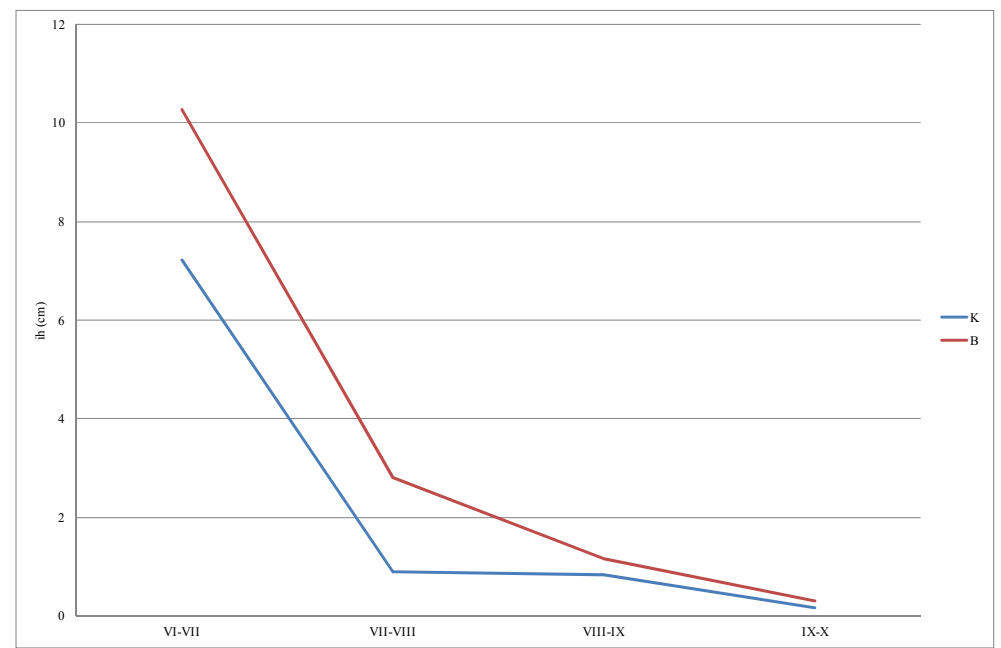

Graph 2. Development of height increment of black walnut (Juglans nigra L.) seedlings during the vegetation period

Based on the obtained results it can be concluded that the microbiological preparation Bactofil is suitable for the production of black walnut seedlings. 
Oršanić, M. et al. (2007) studied the growth and development of black walnut seedlings during the first growing season and nurseries in Zagreb, and measured at the end of the growing season average height of $31.5 \mathrm{~cm}$, which is lower than the average height of seedlings treatment obtained in these studies.

Average heights of seedling of black walnut in this study were comparable with those heights black walnut seedlings of the same age in terms of medium dense sowing (Jacobs, D. F. et al., 2006).

Woeste, K. E. et al. (2011) from the seeds of the black walnut trees in Indiana (USA) produced seedlings whose average height was $45.6 \mathrm{~cm}$, ranging from 37.4 to $51.3 \mathrm{~cm}$.

\section{CONCLUSIONS}

Even the 1978 Grey, T. R. G. et Williams, S. T. (1978) found that microorganisms produce growth hormones (gibberellins, auxins) and vitamins and affect the growth and development of plants. The positive influence of the most in this case is reflected in the black walnut seedlings treated exactly the biofertilizer, because they have reached greater heights, as compared to untreated plants. Seedlings treated with Bactofil in this study show better results than non-treated seedlings. Bigger average heights and absolutely maximal heights have seedlings of black walnut treated with Bactofil.

Microbiological preparation Bactofil positively affects the development of seedlings stimulating the development of seedlings height which is of particular importance if one takes into account that height, along with root collar diameter, is one of the most important morphological criteria of quality of deciduous seedlings (Stilinović, S. 1987).

An easy way of application by adding microbiological preparation Bactofil directly to the substrate speak in favor of justification of application of this preparation in mass production of high quality planting material for different purposes.

\section{Acknowledgement}

The research is financed by the Ministry of Science and Technological Development of the Republic of Serbia, Project TR 31070 "The development of technological procedures in forestry with a view to an optimum forest cover realisation” (2011-2014).

\section{REFERENCES}

Ćirković-Mitrović, T., Brašanac-Bosanac, Lj., Popović, V. (2012): Effect of fertilizer application on morphological characteristics of walnut (Juglans regia L.) juvenile seedlings, International Conference on BioScience: Biotechnology and Biodiversity - Step in the Future, The Forth Joint UNS-PSU Conference, Novi Sad, June 18-20, 2012., Book of Abstracts, p. 94.

Ćirković-Mitrović, T., Popović, V. Brašanac-Bosanac, Lj., Lučić, A., Rakonjac Lj. (2012a): The effect of application of mineral fertilizers and microbiological preparation on radial 
growth of walnut (Juglans regia L.) seedling, International Conference: Forestry science and practice for the purpose of sustainable development of forestry - 20 years of the Faculty of Forestry in Banja Luka. Banja Luka, $1^{\text {th }}-4^{\text {th }}$ November, 2012. Book of Abstracts, p. 93.

Cirkovic-Mitrovic, T., Popović V., Brašanac-Bosanac, Lj., Rakonjac Lj., Lučić A. (2012b): The effect of application of fertilising preparations on height of walnut (Juglans regia L.) seedling, Sustainable Forestry, Tom. 65-66, Institute of Forestry, p. 73-81 , Belgrade. ISSN 1821-1046

Ćirković-Mitrović, T. (2014): Influence of different nutritional preparations on morphoanatomical characteristics of wild fruit seedlings, Doctoral dissertation, Facultyof Forestry, Belgrade, Serbia

Grey, T. R. G., Williams, S. T. (1978): Soil Micro-organisms. Oliver and Boyd, Edinburgh, $1-240$.

Jacobs, D. F., Woeste, K. E., Wilson, B. C., McKenna, J. R. (2006): Stock Quality of Black walnut (Juglans nigra) Seedlings as Affected by Half-Sib Seed Source and Nursery Sowing Density. Proc. Vth Int. Walnut Symp. Eds. M.E. Malvolti and D. Avanzato Acta Hort. 705, ISHS, 375-381.

Oliet, J., A., Planelles, R., Artero, F., Valverde, R., Jacobs, D., F., Segura, M., L. (2009). Field performance of $\mathrm{P}$. halepensis planted in Mediterranean arid conditions: relative influence of seedling morphology and mineral nutrition. New Forest, 37(3): 313-331.

Oršanić, M., Drvodelić, D., Kovačević, I. (2007): Rasadnička proizvodnja sadnica crnoga oraha (Juglans nigra L.) Šumarski list br. 5-6, CXXXI 207-217.

Стилиновић, С. (1987): Производња садног материјала шумског и украсног дрвећа и жбуња. Институт за шумарство - Шумарски факултет, Београд, 1-454.

Woeste, K. E., Jacobs, D. F., McKenna, J. R. (2011): Half-sib seed source and nursery sowing density affect black walnut (Juglans nigra) growth after 5 years. New Forests 41, $235-245$

\title{
THE EFFECT OF APPLICATION OF MICROBIOLOGICAL PREPARATION ON HEIGHT GROWTH DYNAMICS OF ONE-YEAR OLD SEEDLING OF BLACK WALNUTE (Juglans nigra L.)
}

\author{
Tatjana ĆIRKOVIĆ-MITROVIĆ
}

\section{Summary}

Range of many fruit trees in Serbia has declined alarmingly in the past 50 years and production of seedlings and their introduction into existing forests as well as afforestation of bare land contributes to the improvement of natural biological wealth of Serbia.

Based on these results in this paper it was concluded that used nutrition preparations have influence on the level and dynamic height growth of seedlings of black walnut. Microbiological preparation Bactofil positively affects the development of seedlings stimulating the development of seedlings height. The statistical analysis of height of the black walnut seedling upon the treatment by preparations Bactofil indicates that after a more or less uniform increase in height at the beginning of the vegetation period comes to 
an increasing of differentiation of this morphometric marker in plants treated with Bactofil in comparison with the control seedlings.

An easy way of application by adding microbiological preparation Bactofil directly to the substrate speak in favor of justification of application of this preparation in mass production of high quality planting material for different purposes.

\title{
ЕФЕКАТ ПРИМЕНЕ МИКРОБИОЛОШКОГ ПРЕПАРАТА НА ДИНАМИКУ ВИСИНСКИ ПОРАСТА ЈЕДНОГОДИШЫИХ САДНИЦА ЦРНОГ ОРАХА (Juglans nigra L.)
}

\author{
Tatjana ĆIRKOVIĆ-MITROVIĆ
}

\section{Резиме}

Ареал многих воћкарица у последњих 50 година алармантно је смањен, па производња садница и њихово уношење у постојеће шуме и при пошумљавању необраслих површина доприноси унапређењу природног биолошког богатства Србије.

На основу добијених резултата у овом раду констатовано је да коришћење препарата исхране утиче на висину и динамику висинског раста садница црног ораха. Микробиолошки препарат Bactofil позитивно утиче на развој садница стимулишући развој висине садница. Статистичка анализа висине садница црног ораха третираних препаратом Bactofil указује да после мање више уједначеног пораста висина на почетку вегетационог периода, долази до све веће диференцијације овог морфометријског маркера код садница третираних Bactofil-om у односу на контролне саднице.

Једноставан начин примене додавањем ђубрива директно у супстрат приликом његове припреме, контролисано разлагање које прати потребе биљке и релативно дуг период деловања говоре у прилог оправданости примене овог ђубрива у масовној производњи висококвалитетног садног материјала за различите намене. 